\title{
Bird communities in three forest types in the Pernambuco Centre of Endemism, Alagoas, Brazil
}

\author{
Lahert W. Lobo-Araújo ${ }^{1,2}$, Mário T. F. Toledo ${ }^{3}$, Márcio A. Efe ${ }^{1,2}$, Ana C. M. Malhado², Marcos V. C. Vital ${ }^{4}$, \\ Guilherme S. Toledo-Lima ${ }^{5}$, Phoeve Macario ${ }^{5}$, Jhonatan G. dos Santos ${ }^{6}$ \& Richard J. Ladle,7 \\ 1. Laboratório de Bioecologia e Conservação de Aves Neotropicais - ICBS/UFAL, Campus A. C. Simões, Av. Lourival de Melo Mota, km 14, Cidade Universitária, 57072-970 Maceió, AL. \\ (lahertwilliam@hotmail.com) \\ 2. Programa de Pós-Graduação em Diversidade Biológica e Conservação nos Trópicos - ICBS/UFAL, Campus A. C. Simões, Av. Lourival de Melo Mota, km 14, Cidade Universitária, \\ 57072-970 Maceió, AL. \\ 3. Instituto Federal de Alagoas, Campus Satuba, Rua 17 de Agosto s/n ${ }^{\circ}$, centro, Satuba, 57120-000 Maceió, AL \\ 4. Laboratório de Ecologia Quantitativa - ICBS/UFAL, Campus A. C. Simões, Av. Lourival de Melo Mota, km 14, Cidade Universitária, $57072-970$ Maceió, AL. \\ 5. Departamento de Botânica, Ecologia e Zoologia, Centro de Biociências, Universidade Federal do Rio Grande do Norte, Campus Universitário Lagoa Nova, 59072-970, Natal, RN. \\ 6. Instituto de Ciências Biológicas e da Saúde, Universidade Federal de Alagoas, Campus A. C. Simões, Av. Lourival de Melo Mota, km 14, Cidade Universitária, 57072-970 Maceió, AL. \\ 7. School of Geography and the Environment, University of Oxford, South Parks Road, Oxford, OX1 3QY, United Kingdom.
}

\begin{abstract}
The Pernambuco Center of Endemism (PCE) in northeastern Brazil is highly fragmented and degraded. Despite its potential conservation importance the bird fauna in this area is still relatively unknown and there are many remnant fragments that have not been systematically surveyed. Here, we report the results of bird surveys in five forest fragments (one pioneer, two ombrophilous and two seasonal). In total, 162 taxa were recorded, 12 of which are endemic to the PCE. The frequency of endangered species was lower than what has been reported in studies from the same area and most of the taxa considered to be at risk of extinction were sub-species of uncertain taxonomic validity. The comparatively low number of endemic/threatened species may be due to the small size of the fragments in the present study - a consequence of the high levels of habitat loss in this region. Analysis of species richness patterns indicates that ombrophilous forest fragments are acting as refuges for those bird species that are most sensitive to environmental degradation.
\end{abstract}

KEYWORDS. Avifauna, ombrophilous forest, restinga, seasonal forest, species richness.

RESUMO. Comunidade de aves em três tipos florestais no Centro de Endemismo Pernambuco. O Centro de Endemismo Pernambuco (PCE), a área de Floresta Atlântica ao norte do rio São Francisco no nordeste do Brasil é altamente fragmentado e degradado. Apesar de sua importância nacional e global, a avifauna desta área é relativamente pouco estudada e há muitos fragmentos remanescentes que não foram sistematicamente pesquisados. Aqui, nós relatamos os resultados de pesquisas com a avifauna de cinco fragmentos florestais (um de floresta pioneira, dois de floresta ombrófila e dois de floresta sazonal). No total, 162 taxa foram registrados, 12 dos quais são endêmicos do PCE. No geral a frequência de espécies ameaçadas foi mais baixa do que em estudos similares e a maioria dos taxa considerados em risco de extinção foram subespécies de validade taxonômica incerta. Os principais fatores desse contraste podem ser o tamanho relativamente pequeno dos fragmentos do presente estudo e o elevado nível de fragmentação e degradação do habitat. A análise do padrão de riqueza de espécies pode indicar que os fragmentos de floresta ombrófila estão atuando como refúgio importante para espécies de aves que são sensíveis à degradação ambiental.

PALAVRAS-CHAVE. Avifauna, floresta ombrófila, restinga, floresta sazonal, riqueza de espécies.

Information on the geographic distribution of species is essential for predicting the consequences of environmental change for populations and communities. However, such information is frequently lacking, a deficit known as Wallacean shortfall (Lomolino, 2004; Ladle \& WhitTAKer, 2011). Reducing the Wallacean shortfall is especially difficult in geographically large, biodiverse countries such as Brazil where resources and capacity for systematic surveys are limited. For example, there are many areas in Brazil where even comparatively well known taxa such as mammals and birds are poorly documented and surveys are desperately needed to inform conservation and environmental planning (MARINI \& GARCIA, 2005; JETZ et al., 2012).

One of the potentially most important areas for birds in Brazil is also one of the least known. The Pernambuco Center of Endemism (PCE), an area of Atlantic Forest north of São Francisco River in the northeast of the country (PRANCE, 1982; Brown, 1982), is both highly fragmented and poorly studied compared to other areas of the Atlantic Forest (HEYER, 1988;
Collar et al., 1994; Coimbra-Filho \& CÂMara, 1996; Lima \& CAPobianco, 1997; Silva \& Tabarelli, 2001; Silveira et al., 2003; Roda et al., 2011). Based on existing information, there are at least 434 bird species in the PCE, of which 35 species/subspecies are endemic to this region (SiLVEIRA et al., 2003) and 27 are endemic to the Atlantic forest in general (Stotz et al., 1996; RodA et al., 2003). In addition to endemic species, the region also hosts the largest number of endangered bird species in the Americas (Wege \& Long, 1995). Moreover, several of the most threatened endemic Atlantic Forest species have been recorded in the PCE: Gray-breasted Parakeet Pyrrhura griseipectus Salvadori, 1900, Alagoas Foliage-gleaner Philydor novaesi Teixeira \& Gonzaga, 1983, Alagoas Antwren Myrmotherula snowi Teixeira \& Gonzaga, 1985, Orange-bellied Antwren Terenura sicki Teixeira \& Gonzaga, 1983 and Alagoas Tyrannulet Phylloscartes ceciliae Teixeira, 1987 (Olmos, 2005). In total, 40 species/subspecies appear on the Brazilian Ministry of the Environment's (MMA) threatened species list (RoDA et al., 2011) and 22 species/subspecies are on the IUCN Red List (IUCN, 2011). 
The PCE provides an ideal "backdrop" for local extinction due to its combination of agricultural encroachment, deforestation, over-hunting and environmental change (TABARElli \& Peres, 2002). Additional surveys of bird communities of the forest are therefore a priority before rare endemics are eliminated (SilverRA et al., 2003) and to ensure that all species have been discovered. The potential for new discoveries was recently highlighted by the first record of a new species of pigmy owl, the critically endangered Pernambuco Pygmyowl Glaucidium mooreorum Silva, Coelho \& Gonzaga, 2002 in the Saltinho Biological Reserve, Pernambuco (SiLva et al., 2002). This owl may have a population size of less than 50 individuals (BIRDLIFE INTERNATIONAL, 2011).

The main objective of the present study is to describe the bird species composition of five forest remnants of Atlantic Forest in the PCE, covering three distinct vegetation types: pioneer forest, ombrophilous forest and seasonal forest. Our results are discussed in the context of regional conservation planning and the need for further assessments.

\section{MATERIAL AND METHODS}

Study area. The study sites are located in Atlantic forest fragments in state of Alagoas, northeast Brazil (Fig. 1). This area includes four main habitats: pioneer formations (restinga, mangrove and lowland), seasonal forest, ombrophilous forest and cerrado (savannoid vegetation) (Assis, 2000). Although the study sites are limited to the first three habitat types (Tab. I), one of the areas (Catolé Forest) is strongly influence by an enclave of Cerrado. Details of the sites are as follows:

Francês and Barra de São Miguel Restinga (FBR): despite being classified as a Brazilian Permanent Preservation Area (APP), this forest is relatively degraded. It includes floristic elements of the Atlantic Forest and the Caatinga, creating a habitat mosaic of closed vegetation, open vegetation, exposed sandbanks, beaches and marshes. The survey took place in the Dunas do Cavalo Russo and the largest block of continuous forest remnant (180 ha) of this mosaic, known as Francês and Barra de São Miguel Restinga.

Matão Forest (MTF): this fragment has been proposed as a Wildlife Refuge and is the property of Usina Porto Rico, a sugar cane and alcohol agribusiness. This is the most extensive area of Atlantic Forest on flat terrain in state of Alagoas. The trees have a height of approximately $30 \mathrm{~m}$. The climate within the site is seasonal, with approximately 90 dry days per year. The vegetation within the central part of the forest is in good condition and normally shows no adverse effects of drought, even late in the summer (Assis, 2000).

Catole Forest (CTF): This forest is part of the Environmental Protection Area (APA) of Catolé and Fernão Velho. The fragment is connected to a Cerrado enclave (90 ha) and has patches of vegetation at various stages of regeneration. An area of forest that once covered the space around the plateau has now been replaced by the urban expansion of Maceió (Assis, 2000).

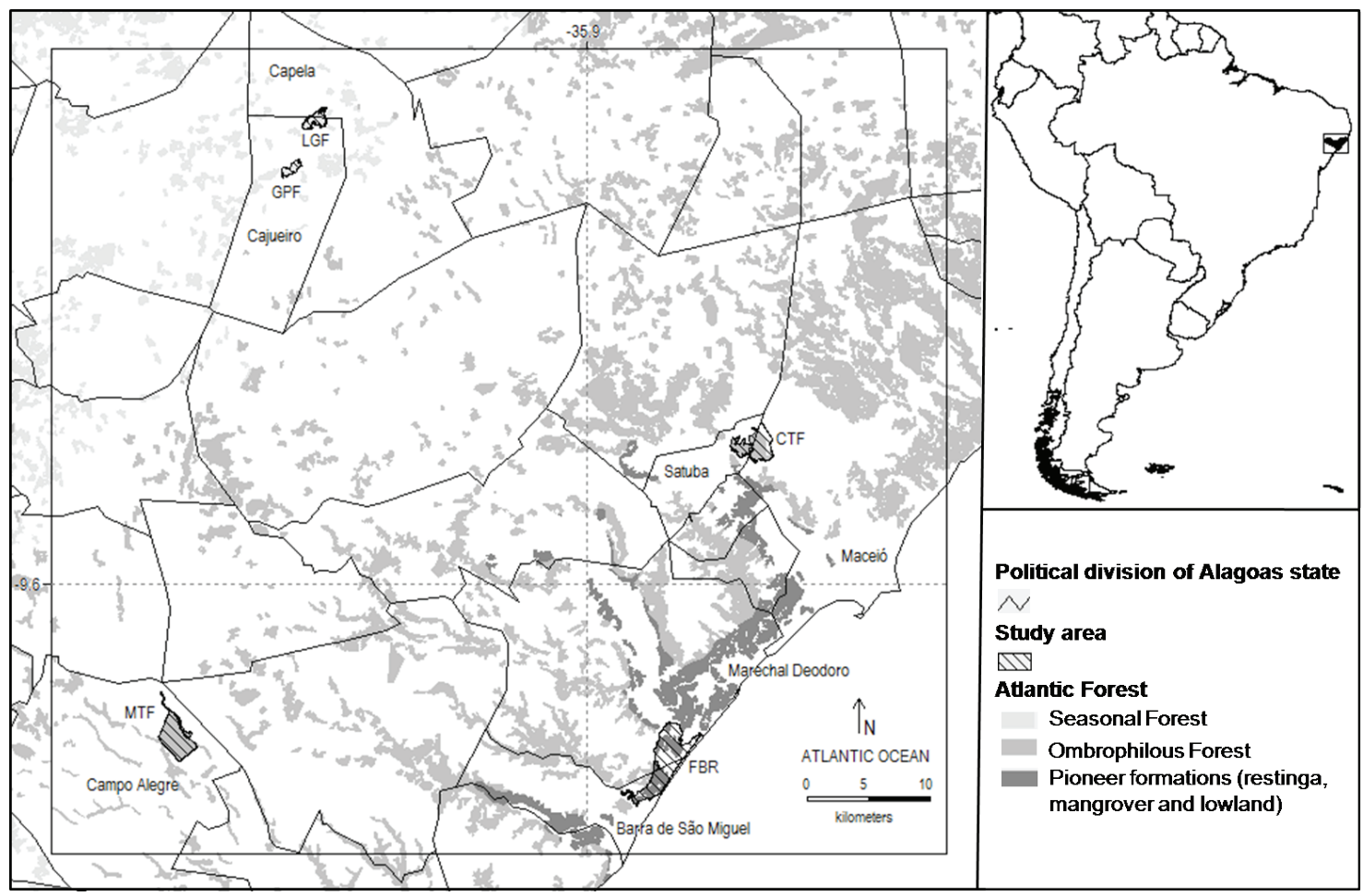

Fig. 1. Location of study areas (FBR, Francês and Barra de São Miguel Restinga; MTF, Matão Forest; CTF, Catolé Forest; LGF, Lagartixa Forest; GPF, Guardiana-Pitimijú Forest) in three habitats of Atlantic Forest in Pernambuco Centre of Endemism, state of Alagoas, Brazil (Source: vegetation cover and mangroves of the state of Alagoas, Alagoas Environment Institute's/PETROBRAS). 
Tab. I. Sites where bird surveys were conducted in state of Alagoas (*, largest remaining fragment of restinga habitat in study area).

\begin{tabular}{|c|c|c|c|c|c|c|}
\hline Site & Location & Altitude (m)/ size (ha) & Habitat & Method & Period & $\begin{array}{l}\text { Visits (days)/ } \\
\text { field hours }\end{array}$ \\
\hline $\begin{array}{l}\text { Francês/Barra } \\
\text { de São Miguel }\end{array}$ & $\begin{array}{l}09^{\circ} 46^{\prime} 10^{\prime \prime} \mathrm{S} \\
35^{\circ} 50^{\prime} 37^{\prime \prime} \mathrm{W}\end{array}$ & $5 / 1270(180)^{*}$ & $\begin{array}{l}\text { Pioneer Formations } \\
\text { (restinga + lowland) }\end{array}$ & Line transects & $\begin{array}{l}\text { February to Sep- } \\
\text { tember } 2006\end{array}$ & $15 / 61$ \\
\hline Matão & $\begin{array}{l}09^{\circ} 46^{\prime} 00 ’ \mathrm{~S} \\
36^{\circ} 14^{\prime} 00^{\prime \prime} \mathrm{W}\end{array}$ & $160 / 690$ & Ombrophilous Forest & $\begin{array}{l}\text { Fixed point } \\
\text { counts }\end{array}$ & $\begin{array}{c}\text { September } 2007 \text { to } \\
\text { August } 2008\end{array}$ & $48 / 100$ \\
\hline Catolé & $\begin{array}{l}09^{\circ} 33^{\prime} 08^{\prime \prime} \mathrm{S} \\
35^{\circ} 47^{\prime} 44^{\prime \prime} \mathrm{W}\end{array}$ & $80 / 590$ & $\begin{array}{l}\text { Ombrophilous Forest } \\
+ \text { Cerrado }\end{array}$ & Line transects & $\begin{array}{c}\text { September } 2005 \\
\text { to November } \\
2006\end{array}$ & $15 / 80$ \\
\hline Lagartixa & $\begin{array}{l}09^{\circ} 18^{\prime} 39^{\prime \prime} \mathrm{S} \\
36^{\circ} 07^{\prime} 49^{\prime \prime} \mathrm{W}\end{array}$ & $402 / 180$ & Seasonal Forest & Line transects & $\begin{array}{c}\text { January } 2003 \text { to } \\
\text { January } 2004\end{array}$ & $7 / 52$ \\
\hline $\begin{array}{l}\text { Guardiana- } \\
\text { Pitimijú }\end{array}$ & $\begin{array}{l}09^{\circ} 20^{\prime} 57^{\prime \prime} \mathrm{S} \\
36^{\circ} 09^{\prime} 09^{\prime \prime} \mathrm{W}\end{array}$ & $39 / 110$ & Seasonal Forest & Line transects & $\begin{array}{c}\text { January } 2003 \text { to } \\
\text { January } 2004\end{array}$ & $27 / 108$ \\
\hline
\end{tabular}

Lagartixa Forest (LGF): this site is one of the best preserved forest fragments in the region and retains many characteristics of primary forest. For example, the understory is generally less dense than in surrounding fragments, the canopy is mainly closed, and there are emergent trees of up to $30 \mathrm{~m}$. The surrounding agricultural matrix consists of sugar cane plantations and cattle pasture.

Guardiana-Pitimiju Forest (GPF): this site contains two fragments, Pitimijú and Guardiana Forests, which were recently (within the past six years) connected. Pitimijú is the smallest fragment, and predominantly consists of secondary forest with small trees $(10-15 \mathrm{~m})$, open canopy and a thick understory. The larger Guardiana Forest site is restricted to an area of hillside and, unlike Pitimijú, contains numerous older trees that may be up to $20 \mathrm{~m}$ in height. The surrounding agricultural matrix consists of sugar cane plantations, fruit trees, pasture and fields of cassava.

Bird Sampling. Between January 2003 and August 2008, were conducted quantitative surveys of the birds associated with the five forest remnants, collecting data in the form of visual and/or auditory records. CTF and FBR were usually visited in the early hours of the day and sometimes at dusk. In the GPF and LGF the study period extended from January 2003 to January 2004 with periodic visits (Tab. I) usually between 5:30 and 11:00 a.m. and sometimes until 3:00 p.m. The trails were covered with constant speed and all contacts with birds, visual or auditory, were noted. The Pitimijú forest was visited 14 times, Guardiana forest 13 times and the Lagartixa forest seven times (Tab. I). The MTF was visited for two consecutive days twice a month from September 2007 to August 2008, totaling 48 field days (Tab. I).

Two survey methods for counts of species and individuals were adopted: unlimited distance transects (BIBBY et al., 2000) for FBR, CTF, LGF and GPF (BIBBY et al., 2000) and fixed point counts (VIELLIARD, 2000) for MTF. Where transects were used, the surveyor utilized existing forest tracks within the first hour of daylight and for an hour before sunset. This transects/ trails were repeated one or more times during the sample period. Sampling was sometimes extended past sunset in order to survey crepuscular and nocturnal birds. For the fixed point method, twelve equidistant points $(200 \mathrm{~m})$ were marked along a track that traversed the fragment. Once again, the census took place in the first hours of daylight and 20 minutes were spent at each fixed point. Sampling points were chosen at random for each visit. Birds were identified with the aid of binoculars and, where appropriate, micro-recorder for analysis of calls and/or songs.

We adopt the taxonomic classification system adopted by CBRO (2011) and SiLveIRA et al. (2003). Data on species and subspecies conservation threat categories were obtained from MACHADO et al. (2008) and IUCN (2011).

Data Analysis. As two distinct methods of data collection were used, sampling units could not be directly compared using a standard rarefaction analysis. Thus, our rarefaction analysis (HURLBERT, 1971) considered each individual as the basic unit of sampling effort, thereby accounting for the influence of the different sampling methods (Gotelli \& Colwell, 2001). This analysis was made with the Analytic Rarefaction 1.3 software (available in http://strata.uga.edu/software/ anRareReadme.html), considering groups of five individuals as a basis for randomization. The comparison of species richness between areas was performed using the number of individuals in the area with less sampling effort as a reference. Statistical inferences about which areas are statistically different with regard the richness was made from the $95 \%$ confidence intervals generated by the rarefaction method. Following Cumming et al. (2007), overlaps between $95 \%$ confidence bars are statistically significant (at $\mathrm{p} \leq 0.05$ ) as long as the bigger overlap between bars is lesser than $50 \%$ the size of the bar.

When the sampling efforts were different, the number of records of each species was converted into an Abundance Index (estimated number of individuals per species in relation to $100 \mathrm{~h}$ of observation) (WILLIS, 1979; WiLlis \& ONIKI, 1981; SilveIRA et al., 2003). 
Tab. II. Abundance Index of species and subspecies endemic to the PCE. Conservation threat status according to the system developed by the Brazilian Ministry of the Environment (MACHADO et al., 2008) [Status (EN, endemic; VU, vulnerable); Study areas (FBR, Francês and Barra de São Miguel Restinga; MTF, Matão Forest; CTF, Catolé Forest; LGF, Lagartixa Forest; GPF, Guardiana-Pitimijú Forest); *, current IUCN Red List category].

\begin{tabular}{|c|c|c|c|c|c|c|}
\hline \multirow[b]{2}{*}{ Species/Subspecies } & \multirow[b]{2}{*}{ Status } & \multirow{2}{*}{$\begin{array}{c}\text { Pioneer } \\
\text { FBR }\end{array}$} & \multicolumn{2}{|c|}{ Ombrophilous } & \multicolumn{2}{|c|}{ Seasonal } \\
\hline & & & $\mathrm{CTF}$ & MTF & LGF & GPF \\
\hline Penelope superciliaris alagoensis & $\mathrm{EN}$ & 9.8 & 0.0 & 6.0 & 0.0 & 0.0 \\
\hline Picumnus exilis pernambucensis & VU & 0.0 & 1.3 & 6.0 & 0.0 & 0.0 \\
\hline Thamnophilus caerulescens pernambucensis & VU & 0.0 & 0.0 & 4.0 & 0.0 & 0.0 \\
\hline Thamnophilus aethiops distans & $\mathrm{EN}$ & 0.0 & 1.3 & 52.0 & 17.3 & 29.6 \\
\hline Pyriglena leuconota pernambucensis & VU & 0.0 & 0.0 & 22.0 & 15.4 & 5.6 \\
\hline Dendrocincla fuliginosa taunayi & $\mathrm{EN}$ & 0.0 & 0.0 & 8.0 & 0.0 & 0.0 \\
\hline Xenops minutus alagoanus & $\mathrm{EN}$ & 0.0 & 0.0 & 25.0 & 0.0 & 0.0 \\
\hline Synallaxis infuscata* & $\mathrm{EN}$ & 0.0 & 0.0 & 0.0 & 0.0 & 8.3 \\
\hline Schiffornis turdinus intermedius & VU & 0.0 & 1.3 & 0.0 & 0.0 & 0.0 \\
\hline Platyrinchus mystaceus niveigularis & VU & 0.0 & 1.3 & 13.0 & 1.9 & 1.9 \\
\hline Tangara fastuosa & VU & 0.0 & 2.5 & 0.0 & 17.3 & 11.1 \\
\hline Tangara cyanocephala corallina & VU & 0.0 & 0.0 & 0.0 & 28.8 & 1.9 \\
\hline
\end{tabular}

\section{RESULTS}

In total, 162 bird taxa (13 identified to subspecies level) were recorded at five locations and three habitats of the Atlantic Forest. These taxa were distributed between 44 families and 18 orders. The four most represented families were the Tyrannidae $(\mathrm{n}=20)$, Thraupidae $(\mathrm{n}=$ $15)$, Trochilidae $(\mathrm{n}=10)$ and Thamnophilidae $(\mathrm{n}=9)$, corresponding to approximately one third of records. Ten subspecies and two species (Synallaxis infuscata Pinto, 1950 and Tangara fastuosa Lesson, 1831) were identified as endemic to the PCE (Tab. II), with another six species or subspecies that are regarded as being restricted to the Atlantic forest (Appendix 1).

The raw number of recorded species varied considerably by habitat type. In the pioneer/restinga forest 62 species were found, three of which are Atlantic
Forest or PCE endemics or threatened (Appendix 1). In the seasonal forest 91 species were registered and 131 species in the ombrophilous forest sites. The ombrophilous forest contained the most endemic and threatened taxa (n $=10$ ), five of which are exclusively found in this type of forest: Picumnus exilis pernambucensis Zimmer, 1947, Thamnophilus caerulescens pernambucensis Naumburg, 1937, Dendrocincla fuliginosa taunayi Pinto, 1939 , Xenops minutus alagoanus Pinto, 1954 and Schiffornis turdinus intermedius Pinto, 1954.

Rarefaction analysis indicated that the Catolé forest site had the greatest species richness, followed by GuardianaPitimijú, Matão, Lagartixa forests and finally the pioneer/ restinga site, Francês and Barra de São Miguel (Tab. III; Fig. 2). When the data is collated by habitat type, the ombrophilous forest has the highest richness, followed by seasonal forest and pioneer/resting forest (Tab. III; Fig. 2).

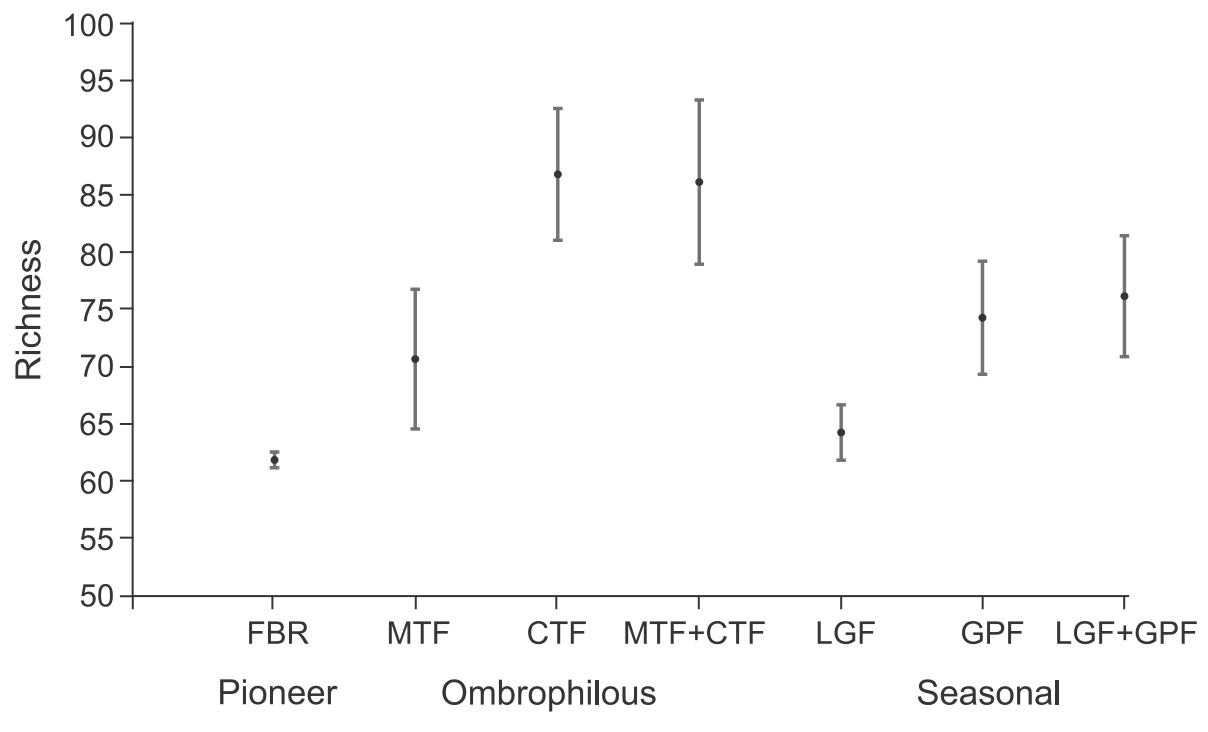

Habitat/Site

Fig. 2. Species richness of study sites and forest habitats, with average values (points) and 95\% confidence intervals (whiskers) from the rarefaction analysis (see text for details). 
Tab. III. Average values and 95\% confidence intervals species richness per site from the rarefaction analysis performed to account for different sampling methods (see text for details) (* largest remaining fragment of restinga habitat in study area).

\begin{tabular}{lccc}
\hline Site & $\begin{array}{c}\text { Species } \\
\text { richness } \\
\text { (rarefacted) }\end{array}$ & $\begin{array}{c}\text { Richness } \\
95 \% \text { CI } \\
\text { lower bound }\end{array}$ & $\begin{array}{c}\text { Richness } \\
95 \% \text { CI } \\
\text { upper bound }\end{array}$ \\
$\begin{array}{l}\text { Francês/Barra de São } \\
\text { Miguel }\end{array}$ & 61.9 & 61.26 & 62.52 \\
Matão & 70.8 & 64.58 & 76.95 \\
Catolé & 86.8 & 81.11 & 92.58 \\
Lagartixa & 65.3 & 61.85 & 66.65 \\
Guardiana-Pitimijú & 74.3 & 69.31 & 79.26 \\
Ombrophilous forest & 86.2 & 79.01 & 93.36 \\
Seasonal forest & 76.2 & 70.9 & 81.43 \\
$\begin{array}{l}\text { Pinoneer / Resting } \\
\text { forest }\end{array}$ & 61.9 & 61.26 & 62.52 \\
\hline
\end{tabular}

\section{DISCUSSION}

We recorded $37.3 \%$ of the total number of bird species registered in the PCE (RoDA et al., 2011). Despite this low percentage, the fragments studied are important for bird conservation in this area. Among the species recorded, some are restricted to the northeast Brazilian states (e.g. Thalurania watertonii; LAS-CASAS \& AZEVEDO-JÚNIOR 2009). Others are specialist species with high sensitivity to disturbance (e.g. Thamnophilus aethiops distans and Dendrocincla fuliginosa taunayi; PARKER et al., 1996). It also hosts generalist species that are more able to cope with deforestation (e.g. Penelope superciliaris alagoensis; SilveIRA et al., 2003).

The sampled communities are composed mainly of insectivores (Tyrannidae, Trochillidae, Thamnophilidae) and small frugivores (Thraupidae). These species are mainly semi and forest independents, demonstrating the high degree of disturbance in the region due to the direct and indirect effects of habitat loss and fragmentation (RANTA et al., 1998; Schulte \& Niemi, 1998; WATSON et al., 2005).

The bird guilds most affected by habitat loss are large frugivores and understory and ground insectivores (Aleixo, 1999; Pizo, 2001). Changes in habitat quality and biotic interactions caused by fragmentation simplify the original communities (SAUNDERS et al., 1991), mainly affecting species more specialized diet. For example, Stouffer \& BierregaArd (1995) reported that understory insectivores, mainly followers of army ants (e.g. P. leuconota), are the first to disappear in response to fragmentation in Amazonia. A similar pattern of loss has been observed in studies in the Atlantic Forest (MotTA, 1990; DonAtelli et al., 2004).

The presence of forest independent or semidependent taxa (e.g. Tyrannidae) (cf. Stouffer \& BierregaARD, 1995; PARKer et al., 1996; EWERS \&
Didham, 2006; Guldemond \& van AARde, 2010) also reflects the loss of large fragments. This is probably because forest dependent species require larger and more complex patches of forest to survive (TURNER, 1996; MARINI, 2001). In the present study, the greatest richness was found at Catolé forest, the third largest fragment by area. This can be cautiously attributed to its greater diversity of microhabitats including numerous small streams, a large reservoir, flooded areas, a varied topography and an adjacent enclave of the cerrado biome (Auto, 1998). The latter is probably responsible for the records of species more typically found in open areas with sparse vegetation such as Hemitriccus margaritaceiventer (d'Orbigny \& Lafresnaye, 1837), Pachyramphus polychopterus (Vieillot, 1818) and Sporophila angolensis (Linnaeus, 1766).

As indicated, Matão forest is the largest remaining fragment on relatively flat terrain in the state of Alagoas. The lack of topographical diversity and the high degree of isolation within an agricultural matrix of sugar cane are probably responsible for the relatively low species richness within this fragment (cf. Williams, 1964; Boecklen, 1986; Terborgh et al., 1997). A history of hunting and selective logging may also have reduced the biodiversity within this site, especially the presence of larger species (JoHns, 1985; BROWN \& BROWN, 1992; Thiollay, 1997; RANTA et al., 1998).

Some species [e.g. Pteroglossus inscriptus Swainson, 1822, Thalurania watertonii and Geranospiza caerulescens (Vieillot, 1817)] were only recorded in the Lagartixa forest (LGF). These species may be dependent on the compositional complexity of trees, shrubs, and herbs specific to this fragment. It should be noted, however, that sampling effort was also lower in this fragment $(52 \mathrm{~h})$ and that the log species accumulation curve had not stabilized by the end of the sampling period.

Our data show that ombrophilous forest fragments contain the highest number of endemic and endangered species and the highest levels of species richness. This forest may therefore be acting as refuge for bird species that are sensitive to environmental degradation and greater natural fluctuations encountered in the sites near the caatinga and restinga biomes.

The agricultural matrix that surrounds forest fragments has been identified as a cause of serious negative impacts on animal communities (LindenMAYER \& Franklin, 2002; Brotons et al., 2003). The FBR site has the largest area, although the largest continuous patch of vegetation within the site is only 180 ha. The relatively low species richness at this site probably reflects its highly fragmented and degraded nature driven by its proximity to neighboring cities, roads and associated human activities. Nevertheless, this site still harbors endemic species and/or endangered species that prefer open 
habitats [Penelope superciliaris alagoensis, Ortalis guttata (Spix, 1825) and Conopophaga cearae lineata (Wied, 1831)] suggesting that the site has significant conservation value. The Rusty-margined Guan (Penelope superciliaris alagoensis) is a large frugivorous species and probably persists in this site due to the numerous piassava palms (Attalea funifera Mart) that occur there.

Given the overall lack of forests specialists, it is not surprising that few of the species recorded in the surveys are considered at global risk of extinction: Thalurania watertonii is classified as 'Near Threatened', T. fastuosa is classified as 'Vulnerable', and only Synallaxis infuscata is considered as 'Endangered' (IUCN, 2011). However, it should be noted that ten species (or subspecies) are classified as Vulnerable and three as Endangered according to the Brazilian Red list (Machado et al., 2008). The Taxa considered as most at risk of extinction (by the IUCN or MMA) are S. infuscata, Penelope superciliaris alagoensis Nardelli, 1993, Thamnophilus aethiops distans Pinto, 1954 and Xenops m. alagoanus, which are endemic or which have few known records in the PCE (Silveira et al., 2003; BARNetT et al., 2005; RoDA et al., 2011). However, it should be noted that there is a degree taxonomic uncertainty over the latter three taxa (and the other subspecies identified in the study) and that the species complex for each of these is classified as Least Concern by the IUCN red list (IUCN, 2011). Of course, this may be changed in the light of new taxonomic analyses to resolve these uncertainties.

It is clear that despite the very high species richness there are very few (taxonomically accepted) species in the study fragments that are considered as globally threatened. The exception was Synallaxis infuscata, classified as Endangered by the IUCN (IUCN, 2011) and recorded at low densities in the GPF seasonal forest site. This species is typically restricted to more open areas within forests and can often be found where trees have been felled - a common practice in the GPF site.

The relatively low levels of threatened species recorded in the present survey are in contrast with the results of BARNETT et al. (2005), who reported 32 threatened and endemic birds including a new species during surveys of sites situated in the mountains of state of Pernambuco (also within the PCE). The main factors driving this contrast may be the relatively small size of the fragments in the present study and the high level of habitat degradation. Thus, it is quite likely that some endemic and/or threatened birds may have already disappeared from these fragments and, given the prospects for reforestation, are unlikely to return. The potential loss of rare and endemic species from forest fragments in the PCE indicates the urgent need for a greater number of systematic surveys of the bird fauna of this region.

Acknowledgements. Thanks to the Usina Porto Rico for logistical and financial support and the Usina Capricho for providing the data; Aliete Machado and Erikson de Melo for field support; Edelmo de M. Gonçalves Fernando Pacheco, Fábio Olmos and Luiz F. Silveira for taxonomic support; Alvaro Flavinelle, Micheline Maria, Barnagleison Lisboa, Ingrid Caroline, Vinícius Barros, Edson de Almeida and Eliel de Almeida helped in the field work; Dr. Gabrie Omar Skuk Sugliano (in memoriam) for his guidance; Marcelo Cardoso and Sidnei Sampaio for bibliographic advise; Sinval Autran for geographical data and for allowing access to the database of vegetation cover for Alagoas.

\section{REFERENCES}

ANJos, J. S. 2006. Bird species sensitivity in a fragmented landscape of the Atlantic Forest in Southern Brazil. Biotropica 38:220-234.

Assis, J. S. 2000. Biogeografia e Conservação da Biodiversidade: projecões para Alagoas. Maceió, Catavento. 200p.

Auto, P. C. C. 1998. Unidades de Conservação em Alagoas. Maceió, IBAMA. 239p.

Barnett, J. M.; Carlos, C. J. \& Roda, S. A. 2005. Renewed hope for the threatened avian endemics of northeastern Brazil. Biodiversity and Conservation 14:2265-2274.

Bibby, C. J.; Burgess, N. D.; Hill, D. A. \& Mustoe, S. H. 2000. Bird census techniques. 2ed. London, Academic Press. $277 \mathrm{p}$.

BirdLIFE InTERNATIONAL. 2011. Species factsheet: Glaucidium mooreorum. Available at $<\mathrm{http} / / / \mathrm{www}$.birdlife.org $>$. Accessed on April, 2012.

BoecKLen, W. J. 1986. Effects of habitat heterogeneity on the speciesarea relationships of forest birds. Journal of Biogeography 13:59-68.

Brotons, L.; MonkKonen, M. \& Martin, J. L. 2003. Are fragments islands? Landscape context and density-area relationships in Boreal forest birds. The American Naturalist 162:344-357.

BRown, K. S. 1982. Paleoecology and regional patterns of evolution in neotropical forest butterflies. In: PrAnCE, G. T. ed. Biological Diversification in the Tropics. New York, Columbia University Press. p. 255-308.

Brown, K. S. \& Brown, G. G. 1992. Habitat alteration and species loss in Brazilian forest. In: Whitmore, T. C. \& SAYer, J. A. eds. Tropical Forest and Extinction. London, Chapman \& Hall. 156 $\mathrm{p}$

CBRO - Comitê Brasileiro de Registros Ornitológicos. 2011. Listas das Aves do Brasil. 10ed. Available at: <http://www.cbro.org. br>. Accessed on: April, 2012

Coimbra-Filho, A. \& CÂmara, I. G. 1996. Os limites originais do bioma Mata Atlântica na Região Nordeste do Brasil. Rio de Janeiro, FBCN. 86p.

Collar, N. J.; Crosby, M. J. \& Stattersfield, A. J. 1994. Birds to watch 2: the world list of threatened birds. Washington DC, BirdLife International, Smithsonian Institution Press. 407p.

Cumming, G.; Fidler, F. \& Vaux, D. L. 2007. Error bars in experimental biology. Journal of Cell Biology 177(1):7-11.

Ewers, R. M. \& Didham, R. K. 2006. Confounding factors in the detection of species responses to habitat fragmentation. Biological Reviews 81:117-142.

Gotelli, N. J. \& Colwell, R. K. 2001. Quantifying biodiversity: procedures and pitfalls in the measurement and comparison of species richness. Ecology Letters 4:379-391.

Guldemond, R. A. R. \& van Aarde, R. J. 2010. Forest patch size and isolation as drivers of bird species richness in Maputaland, Mozambique. Journal of Biogeography 37:1884-1893.

HeYer, W. R. 1988. On frog distribution patterns east of the Andes. In: Vanzolini, P. E. \& Heyer, W. R. eds. Proceedings of a Workshop on Neotropical Distribution Patterns. Rio de Janeiro, Academia Brasileira de Ciências. 488 p.

HurlberT, S. H. 1971. The nonconcept of species diversity: a critique and alternative parameters. Ecology 52:577-586.

IUCN. 2011. IUCN Red List of Threatened Species. Version 2011.2. Available at: <www.iucnredlist.org $>$. Accessed on: December, 2011 
Jetz, W.; McPherson, J. M. \& Guaralnick, R. P. 2012. Integrating biodiversity distribution knowledge: toward a global map of life. Trends in Ecology and Evolution 27:151-159.

JoHNS, A. D. 1985. Selective logging and wildlife conservation in tropical rain forests: problems and recommendations. Biological Conservation 31:355-375.

Ladle, R. J. \& Whittaker, R. J. 2011. Conservation Biogeography. Oxford, Blackwell Publishing. 320p.

Las-Casas, F. M. G. \& Azevedo-Júnior, S. M. 2009. Dimorfismo sexual de tamanho no beija-flor-de-costas-violetas Thalurania watertonii (Bourcier, 1847) (Aves: Trochilidae): implicações ecológicas. Ornithologia 3:83-89.

Lima, A. R. \& CAPobianco, J. P. R. 1997. Mata Attântica: avanços legais e institucionais para a sua conservação. Documentos ISA $\mathrm{n}^{\circ}$ 4. São Paulo, Instituto Socioambiental.

Lindenmayer, D. B. \& Franklin, J. F. 2002. Conserving forest biodiversity: a comprehensive multiscale approach. Washington DC, Island Press. 351p.

Lomolino, M. V. 2004. Conservation biogeography. In: Lomolino, M. V. \& Heaney, L. R. eds. Frontiers of Biogeography: new directions in the geography of nature. Sunderland, Sinauer Associates. p. 293-296.

Machado, A. B. M.; Drummond, G. M. \& Paglia, A. P. eds. 2008. Livro vermelho da fauna brasileira ameaçada de extinção. Brasília, Ministério do Meio Ambiente, Fundação Biodiversitas. 1420p.

MARINI, M. A. 2001. Effects of forest fragmentation on birds of the Cerrado region, Brazil. Bird Conservation International 11:1123.

Marini, M. A. \& Garcia, F. I. 2005. Conservação de Aves no Brasil. Megadiversidade 1:95-102.

Olmos, F. 2005. Aves ameaçadas, prioridades e políticas de conservação no Brasil. Natureza \& Conservação 3:21-42.

Parker, T. A.; Stotz, D. F. \& FitzPatrick, J. W. 1996. Ecological and distributional databases. In: Stotz, D. F.; FitZPatrick, J. W.; PARKer III, T. A. \& Moskovits, D. K. eds. Neotropical birds: ecology and conservation. Chicago, University of Chicago Press. $502 \mathrm{p}$.

Prance, G. T. 1982. Forest refuges: evidences from woody angiosperms. In: Prance, G. T. ed. Biological diversification in the tropics. New York, Columbia University Press. 714p.

Ranta, P.; Blomt, T.; Niemela, J.; JoensuU, E. \& Sittonen, M. 1998. The fragmented Atlantic rain forest of Brazil: size, shape and distribution of forest fragments. Biodiversity and Conservation 7:385-403.

Roda, S.; Pereira, G. A. \& Albano, C. 2011. Conservação de Aves Endêmicas e Ameaçadas do Centro de Endemismo Pernambuco. Recife, Ed. Universitária da UFPE. 79p.
Roda, S. A.; Carlos, C. J. \& Rodrigues, R. C. 2003. New and noteworthy records for some endemic and threatened birds of the Atlantic forest of north-eastern Brazil. Bulletin of the British Ornithological Club 123(4):227-236

Schulte, L. A. \& Niemi, G. J. 1998. Bird communities of early successional burned and logged forest. Journal of Wildlife Management 62:1418-1429.

Silva, J. M. C.; Coelho, G. \& Gonzaga, L. A. P. 2002. Discovered on the brink of extinction a new species of pygmy-owl (Strigidae: Glaucidium) from Atlantic Forest of northeastern Brazil. Ararajuba 10:123-130.

Silva, J. M. C. \& Tabarelli, M. 2001. The future of Atlantic forest in northeastern Brazil. Conservation Biology 15:819-820.

Silveira, L. F.; Olmos, F. \& Long, A. J. 2003. Birds in Atlantic Forest fragments in north-east Brazil. Cotinga 20:32-46.

Stouffer, P. C. \& BierregaArd, Jr., R. O. 1995. Use of Amazonian forest fragments by understory insectivorous birds. Ecology 76:2429-2445.

Tabarelli, M. \& Peres, C. A. 2002. Abiotic and vertebrate seed dispersal in the Brazilian Atlantic forest: implications for forest regeneration. Biological Conservation 106:165-176.

Terborgh, J.; LopeZ, L.; Tello, J.; Yu, D. \& BrunNI, A. R. 1997. Transitory states in relaxing ecosystems of land bridge islands. In: Laurance, W. F. \& Bierregaard, R. O. eds. Tropical forest remnants: ecology, management and conservation of fragmented communities. Chicago, University of Chicago Press. 632p.

Thiollay, J. M. 1997. Disturbance, selective logging and bird diversity: a Neotropical forest study. Biodiversity and Conservation 6:1155-1173

TURNER, I. M. 1996. Species loss in fragments of tropical rain forest: a review of the evidence. Journal of Applied Ecology 33:200-219

VIelliard, J. M. E. 2000. Bird community as an indicator of biodiversity: results from quantitative surveys in Brazil. Anais da Academia Brasileira de Ciências 72:323-330.

Watson, J. E. M.; Whittaker, R. J. \& Freudenberger, D. 2005. Bird community responses to habitat fragmentation: how consistent are they across landscapes? Journal of Biogeography 32:1353-1370.

Wege, D. C. \& LonG, A. 1995. Key areas for threatened birds in the tropics. BirdLife Conservation Series 5:75-80

Williams, C. B. 1964. Patterns in the balance of nature and related problems in quantitative ecology. New York, Academic Press. $324 \mathrm{p}$.

WiLlis, E. O. 1979. The composition of avian communities in remanescent woodlots in southern Brazil. Papéis Avulsos de Zoologia 33:1-25.

WiLLIS, E. O. \& ONIKI, Y. 1981. Levantamento preliminar de aves em treze áreas do Estado de São Paulo. Revista Brasileira de Biologia 41:121-135.

Appendix 1. Abundance Index and conservation risk status of species in the 5 study sites (IUCN categories: LC, least concern; NT, near threatened; V, vulnerable; EN, endangered. *, Atlantic Forest endemic; ${ }^{* *}$, PCE endemic; ${ }^{\bullet}$, species detected during nocturnal sampling). ${ }^{1}$, Conservation threat status of subspecies according to the system developed by the Brazilian Ministry of the Environment (MACHADO et al., 2008).

\begin{tabular}{|c|c|c|c|c|c|c|}
\hline \multirow[b]{2}{*}{ Family/Species } & \multirow[b]{2}{*}{ IUCN } & \multirow{2}{*}{$\begin{array}{c}\text { Pioneer } \\
\text { FBR }\end{array}$} & \multicolumn{2}{|c|}{ Ombrophilous } & \multicolumn{2}{|c|}{ Seasonal } \\
\hline & & & CTF & MTF & LGF & GPF \\
\hline \multicolumn{7}{|l|}{ Tinamidae (4) } \\
\hline Crypturellus soui & $\mathrm{LC}$ & 0.0 & 7.5 & 4.0 & 0.0 & 0.0 \\
\hline Crypturellus strigulosus & $\mathrm{LC}$ & 0.0 & 0.0 & 7.0 & 0.0 & 0.0 \\
\hline Crypturellus parvirostris & $\mathrm{LC}$ & 0.0 & 0.0 & 6.0 & 0.0 & 1.9 \\
\hline Rhynchotus rufescens & $\mathrm{LC}$ & 0.0 & 0.0 & 0.0 & 1.9 & 4.6 \\
\hline \multicolumn{7}{|l|}{ Cracidae (2) } \\
\hline Ortalis guttata $^{*}$ & $\mathrm{LC}$ & 11.5 & 0.0 & 0.0 & 0.0 & 1.9 \\
\hline Penelope superciliaris alagoensis ${ }^{* *}$ & $\mathrm{EN}^{1}$ & 9.8 & 0.0 & 6.0 & 0.0 & 0.0 \\
\hline \multicolumn{7}{|l|}{ Ardeidae (2) } \\
\hline Tigrisoma lineatum & $\mathrm{LC}$ & 0.0 & 0.0 & 1.0 & 0.0 & 0.0 \\
\hline Butorides striata & $\mathrm{LC}$ & 1.6 & 0.0 & 0.0 & 0.0 & 0.0 \\
\hline Cathartidae (3) & & & & & & \\
\hline
\end{tabular}


Appendix 1. Continued.

\begin{tabular}{|c|c|c|c|c|c|c|}
\hline \multirow[b]{2}{*}{ Family/Species } & \multirow[b]{2}{*}{ IUCN } & \multirow{2}{*}{$\begin{array}{c}\text { Pioneer } \\
\text { FBR }\end{array}$} & \multicolumn{2}{|c|}{ Ombrophilous } & \multicolumn{2}{|c|}{ Seasonal } \\
\hline & & & CTF & MTF & LGF & GPF \\
\hline \multicolumn{7}{|l|}{ Cathartidae (3) } \\
\hline Cathartes aura & $\mathrm{LC}$ & 42.6 & 21.3 & 15.0 & 5.8 & 26.9 \\
\hline Cathartes burrovianus & $\mathrm{LC}$ & 4.9 & 1.3 & 0.0 & 0.0 & 0.0 \\
\hline Coragyps atratus & $\mathrm{LC}$ & 57.4 & 35.0 & 4.0 & 9.6 & 17.6 \\
\hline \multicolumn{7}{|l|}{ Accipitridae (6) } \\
\hline Geranospiza caerulescens & $\mathrm{LC}$ & 0.0 & 0.0 & 0.0 & 1.9 & 0.0 \\
\hline Rupornis magnirostris & $\mathrm{LC}$ & 31.1 & 17.5 & 16.0 & 5.8 & 16.7 \\
\hline Geranoaetus albicaudatus & $\mathrm{LC}$ & 0.0 & 5.0 & 1.0 & 0.0 & 0.0 \\
\hline Buteo nitidus & $\mathrm{LC}$ & 0.0 & 0.0 & 3.0 & 0.0 & 0.0 \\
\hline Buteo brachyurus & $\mathrm{LC}$ & 1.6 & 2.5 & 1.0 & 1.9 & 6.5 \\
\hline Buteo albonotatus & $\mathrm{LC}$ & 0.0 & 1.3 & 0.0 & 1.9 & 3.7 \\
\hline \multicolumn{7}{|l|}{ Falconidae (4) } \\
\hline Caracara plancus & $\mathrm{LC}$ & 55.7 & 8.8 & 7.0 & 3.8 & 11.1 \\
\hline Milvago chimachima & $\mathrm{LC}$ & 3.3 & 2.5 & 0.0 & 11.5 & 1.9 \\
\hline Herpetotheres cachinnans & $\mathrm{LC}$ & 0.0 & 1.3 & 11.0 & 0.0 & 1.9 \\
\hline Falco sparverius & $\mathrm{LC}$ & 0.0 & 0.0 & 1.0 & 0.0 & 0.9 \\
\hline \multicolumn{7}{|l|}{ Rallidae (1) } \\
\hline Aramides cajanea & $\mathrm{LC}$ & 0.0 & 0.0 & 2.0 & 0.0 & 0.0 \\
\hline \multicolumn{7}{|l|}{ Charadriidae (1) } \\
\hline Vanellus chilensis & $\mathrm{LC}$ & 8.2 & 3.8 & 3.0 & 0.0 & 0.0 \\
\hline \multicolumn{7}{|l|}{ Jacanidae (1) } \\
\hline Jacana jacana & $\mathrm{LC}$ & 1.6 & 0.0 & 0.0 & 0.0 & 0.0 \\
\hline \multicolumn{7}{|l|}{ Columbidae (6) } \\
\hline Columbina minuta & $\mathrm{LC}$ & 1.6 & 0.0 & 0.0 & 0.0 & 0.0 \\
\hline Columbina talpacoti & $\mathrm{LC}$ & 16.4 & 13.8 & 5.0 & 0.0 & 9.3 \\
\hline Columbina squammata & $\mathrm{LC}$ & 16.4 & 1.3 & 0.0 & 0.0 & 2.8 \\
\hline Patagioenas cayennensis & $\mathrm{LC}$ & 6.6 & 0.0 & 17.0 & 0.0 & 0.0 \\
\hline Leptotila verreauxi & $\mathrm{LC}$ & 0.0 & 7.5 & 53.0 & 21.2 & 13.0 \\
\hline Leptotila rufaxilla & $\mathrm{LC}$ & 0.0 & 10.0 & 1.0 & 0.0 & 0.0 \\
\hline \multicolumn{7}{|l|}{ Psittacidae (6) } \\
\hline Diopsitta canobilis & $\mathrm{LC}$ & 0.0 & 20.0 & 25.0 & 67.3 & 26.9 \\
\hline Aratinga aurea & $\mathrm{LC}$ & 1.6 & 1.3 & 0.0 & 0.0 & 0.0 \\
\hline Forpus xanthopterygius & $\mathrm{LC}$ & 6.6 & 0.0 & 1.0 & 0.0 & 8.3 \\
\hline Pionus reichenowi & $\mathrm{LC}$ & 0.0 & 1.3 & 0.0 & 0.0 & 0.0 \\
\hline Pionus maximiliani & $\mathrm{LC}$ & 0.0 & 0.0 & 33.0 & 0.0 & 0.0 \\
\hline Amazona amazonica & $\mathrm{LC}$ & 0.0 & 0.0 & 74.0 & 0.0 & 0.0 \\
\hline \multicolumn{7}{|l|}{ Cuculidae (4) } \\
\hline Piaya cayana & $\mathrm{LC}$ & 23.0 & 12.5 & 34.0 & 7.7 & 19.4 \\
\hline Crotophaga ani & $\mathrm{LC}$ & 18.0 & 1.3 & 1.0 & 25.0 & 17.6 \\
\hline Guira guira & $\mathrm{LC}$ & 1.6 & 0.0 & 0.0 & 7.7 & 2.8 \\
\hline Tapera naevia & $\mathrm{LC}$ & 0.0 & 0.0 & 0.0 & 1.9 & 2.8 \\
\hline \multicolumn{7}{|l|}{ Tytonidae (1) } \\
\hline Tyto alba & $\mathrm{LC}$ & 1.6 & 0.0 & 0.0 & 0.0 & 0.0 \\
\hline \multicolumn{7}{|l|}{ Strigidae (1) } \\
\hline Glaucidium brasilianum ${ }^{\bullet}$ & $\mathrm{LC}$ & 0.0 & 0.0 & 0.0 & 3.8 & 3.7 \\
\hline \multicolumn{7}{|l|}{ Caprimulgidae (3) } \\
\hline Caprimulgus rufus ${ }^{\bullet}$ & LC & 0.0 & 1.3 & 0.0 & 0.0 & 0.0 \\
\hline
\end{tabular}


Appendix 1. Continued.

\begin{tabular}{|c|c|c|c|c|c|c|}
\hline \multirow[b]{2}{*}{ Family/Species } & \multirow[b]{2}{*}{ IUCN } & \multirow{2}{*}{$\begin{array}{c}\text { Pioneer } \\
\text { FBR }\end{array}$} & \multicolumn{2}{|c|}{ Ombrophilous } & \multicolumn{2}{|c|}{ Seasonal } \\
\hline & & & $\mathrm{CTF}$ & MTF & LGF & GPF \\
\hline Hydropsalis albicollis ${ }^{\bullet}$ & $\mathrm{LC}$ & 6.6 & 2.5 & 1.0 & 0.0 & 0.0 \\
\hline Hydropsalis torquata & $\mathrm{LC}$ & 0.0 & 3.8 & 0.0 & 0.0 & 0.0 \\
\hline \multicolumn{7}{|l|}{ Apodidae (1) } \\
\hline Panyptila cayennensis & $\mathrm{LC}$ & 0.0 & 0.0 & 0.0 & 3.8 & 1.9 \\
\hline \multicolumn{7}{|l|}{ Trochilidae (10) } \\
\hline Phaethornis ruber & $\mathrm{LC}$ & 0.0 & 10.0 & 72.0 & 11.5 & 12.0 \\
\hline Phaethornis pretrei & $\mathrm{LC}$ & 0.0 & 3.8 & 0.0 & 0.0 & 0.0 \\
\hline Eupetomena macroura & $\mathrm{LC}$ & 0.0 & 10.0 & 0.0 & 0.0 & 0.9 \\
\hline Florisuga fusca ${ }^{*}$ & $\mathrm{LC}$ & 0.0 & 0.0 & 0.0 & 0.0 & 2.8 \\
\hline Anthracothorax nigricollis & $\mathrm{LC}$ & 0.0 & 1.3 & 0.0 & 0.0 & 0.0 \\
\hline Chrysolampis mosquitus & $\mathrm{LC}$ & 0.0 & 0.0 & 0.0 & 0.0 & 1.9 \\
\hline Chlorostilbon notatus & $\mathrm{LC}$ & 9.8 & 15.0 & 0.0 & 0.0 & 0.0 \\
\hline Chlorostilbon lucidus & $\mathrm{LC}$ & 0.0 & 0.0 & 1.0 & 30.8 & 8.3 \\
\hline Thalurania watertonii ${ }^{*}$ & NT & 0.0 & 1.3 & 0.0 & 7.7 & 0.0 \\
\hline Amazilia leucogaster & $\mathrm{LC}$ & 0.0 & 5.0 & 0.0 & 0.0 & 0.0 \\
\hline \multicolumn{7}{|l|}{ Trogonidae (1) } \\
\hline Trogon curucui & $\mathrm{LC}$ & 0.0 & 0.0 & 64.0 & 0.0 & 0.0 \\
\hline \multicolumn{7}{|l|}{ Alcedinidae (1) } \\
\hline Megaceryle torquata & $\mathrm{LC}$ & 0.0 & 2.5 & 3.0 & 0.0 & 3.7 \\
\hline \multicolumn{7}{|l|}{ Galbulidae (1) } \\
\hline Galbula ruficauda & $\mathrm{LC}$ & 6.6 & 36.3 & 72.0 & 0.0 & 6.5 \\
\hline \multicolumn{7}{|l|}{ Bucconidae (1) } \\
\hline Nystalus maculatus & $\mathrm{LC}$ & 1.6 & 0.0 & 0.0 & 0.0 & 0.0 \\
\hline \multicolumn{7}{|l|}{ Ramphastidae (1) } \\
\hline Pteroglossus inscriptus & $\mathrm{LC}$ & 0.0 & 0.0 & 0.0 & 11.5 & 0.0 \\
\hline \multicolumn{7}{|l|}{ Picidae (5) } \\
\hline Picumnus exilis pernambucensis ${ }^{* *}$ & $\mathrm{VU}^{1}$ & 0.0 & 1.3 & 6.0 & 0.0 & 0.0 \\
\hline Picumnus cirratus & $\mathrm{LC}$ & 0.0 & 1.3 & 4.0 & 0.0 & 0.0 \\
\hline Veniliornis affinis & $\mathrm{LC}$ & 0.0 & 1.3 & 0.0 & 0.0 & 0.0 \\
\hline Veniliornis passerinus & $\mathrm{LC}$ & 0.0 & 0.0 & 11.0 & 0.0 & 0.0 \\
\hline Campephilus melanoleucos & $\mathrm{LC}$ & 0.0 & 1.3 & 19.0 & 0.0 & 0.0 \\
\hline \multicolumn{7}{|l|}{ Thamnophilidae (9) } \\
\hline Myrmotherula axillaris & $\mathrm{LC}$ & 0.0 & 1.3 & 147.0 & 0.0 & 0.0 \\
\hline Formicivora grisea & $\mathrm{LC}$ & 65.6 & 27.5 & 117.0 & 1.9 & 2.8 \\
\hline Dysithamnus mentalis & $\mathrm{LC}$ & 0.0 & 0.0 & 56.0 & 19.2 & 2.8 \\
\hline Herpsilochmus rufimarginatus & $\mathrm{LC}$ & 0.0 & 11.3 & 183.0 & 0.0 & 0.0 \\
\hline Thamnophilus pelzelni & $\mathrm{LC}$ & 16.4 & 2.5 & 3.0 & 0.0 & 0.0 \\
\hline Thamnophilus caerulescens pernambucensis ${ }^{* *}$ & VU & 0.0 & 0.0 & 4.0 & 0.0 & 0.0 \\
\hline Thamnophilus aethiops distans ${ }^{* *}$ & $\mathrm{EN}^{1}$ & 0.0 & 1.3 & 52.0 & 17.3 & 29.6 \\
\hline Taraba major & $\mathrm{LC}$ & 0.0 & 0.0 & 0.0 & 1.9 & 1.9 \\
\hline Pyriglena leuconota pernambucensis ${ }^{* *}$ & $\mathrm{VU}^{1}$ & 0.0 & 0.0 & 22.0 & 15.4 & 5.6 \\
\hline \multicolumn{7}{|l|}{ Conopophagidae (2) } \\
\hline Conopophaga lineata cearae & $\mathrm{VU}^{1}$ & 4.9 & 0.0 & 0.0 & 0.0 & 0.9 \\
\hline Conopophaga melanops nigrifrons & $\mathrm{VU}^{1}$ & 0.0 & 3.8 & 19.0 & 0.0 & 0.0 \\
\hline \multicolumn{7}{|l|}{ Dendrocolaptidae (4) } \\
\hline Dendrocincla fuliginosa taunayi ${ }^{* *}$ & $\mathrm{EN}^{1}$ & 0.0 & 0.0 & 8.0 & 0.0 & 0.0 \\
\hline Sittasomus griseicapillus & $\mathrm{LC}$ & 0.0 & 6.3 & 2.0 & 25.0 & 18.5 \\
\hline
\end{tabular}


Appendix 1. Continue.

\begin{tabular}{|c|c|c|c|c|c|c|}
\hline \multirow[b]{2}{*}{ Family/Species } & \multirow[b]{2}{*}{ IUCN } & \multirow{2}{*}{$\begin{array}{c}\text { Pioneer } \\
\text { FBR }\end{array}$} & \multicolumn{2}{|c|}{ Ombrophilous } & \multicolumn{2}{|c|}{ Seasonal } \\
\hline & & & CTF & MTF & LGF & GPF \\
\hline Xiphorhynchus guttatus & $\mathrm{LC}$ & 1.6 & 6.3 & 28.0 & 0.0 & 0.0 \\
\hline Dendroplex picus & $\mathrm{LC}$ & 1.6 & 7.5 & 11.0 & 5.8 & 13.9 \\
\hline \multicolumn{7}{|l|}{ Furnariidae (4) } \\
\hline Xenops minutus alagoanus ${ }^{* *}$ & $\mathrm{VU}^{1}$ & 0.0 & 0.0 & 25.0 & 0.0 & 0.0 \\
\hline Phacellodomus rufifrons & $\mathrm{LC}$ & 0.0 & 0.0 & 0.0 & 0.0 & 15.7 \\
\hline Synallaxis infuscata** & $\mathrm{EN}$ & 0.0 & 0.0 & 0.0 & 0.0 & 8.3 \\
\hline Synallaxis frontalis & $\mathrm{LC}$ & 0.0 & 1.3 & 1.0 & 0.0 & 10.2 \\
\hline \multicolumn{7}{|l|}{ Pipridae (4) } \\
\hline Neopelma pallescens & $\mathrm{LC}$ & 0.0 & 1.3 & 1.0 & 0.0 & 0.0 \\
\hline Pipra rubrocapilla & $\mathrm{LC}$ & 0.0 & 16.3 & 74.0 & 15.4 & 0.0 \\
\hline Manacus manacus & $\mathrm{LC}$ & 1.6 & 15.0 & 6.0 & 32.7 & 17.6 \\
\hline Chiroxiphia pareola & $\mathrm{LC}$ & 0.0 & 36.3 & 273.0 & 73.1 & 25.9 \\
\hline \multicolumn{7}{|l|}{ Tityridae (3) } \\
\hline Schiffornis turdinus intermedius ${ }^{* *}$ & $\mathrm{VU}^{1}$ & 0.0 & 1.3 & 0.0 & 0.0 & 0.0 \\
\hline Pachyramphus viridis & $\mathrm{LC}$ & 0.0 & 0.0 & 0.0 & 0.0 & 1.9 \\
\hline Pachyramphus polychopterus & $\mathrm{LC}$ & 0.0 & 1.3 & 0.0 & 0.0 & 1.9 \\
\hline \multicolumn{7}{|l|}{ Incertae sedis (1) } \\
\hline Platyrinchus mystaceus niveigularis ${ }^{* *}$ & $\mathrm{VU}^{1}$ & 0.0 & 1.3 & 13.0 & 1.9 & 1.9 \\
\hline \multicolumn{7}{|l|}{ Rhynchocyclidae (7) } \\
\hline Mionectes oleagineus & $\mathrm{LC}$ & 0.0 & 0.0 & 4.0 & 0.0 & 0.0 \\
\hline Leptopogon amaurocephalus & $\mathrm{LC}$ & 0.0 & 0.0 & 21.0 & 0.0 & 0.0 \\
\hline Tolmomyias flaviventris & $\mathrm{LC}$ & 23.0 & 60.0 & 100.0 & 28.8 & 27.8 \\
\hline Todirostrum cinereum & $\mathrm{LC}$ & 8.2 & 28.8 & 5.0 & 3.8 & 26.9 \\
\hline Poecilotriccus plumbeiceps & $\mathrm{LC}$ & 0.0 & 0.0 & 0.0 & 1.9 & 13.9 \\
\hline Hemitriccus griseipectus & $\mathrm{LC}$ & 0.0 & 8.8 & 229.0 & 0.0 & 0.0 \\
\hline Hemitriccus margaritaceiventer & $\mathrm{LC}$ & 24.6 & 16.3 & 0.0 & 0.0 & 0.0 \\
\hline \multicolumn{7}{|l|}{ Tyrannidae (20) } \\
\hline Hirundinea ferruginea & $\mathrm{LC}$ & 0.0 & 0.0 & 0.0 & 0.0 & 1.9 \\
\hline Ornithion inerme & $\mathrm{LC}$ & 0.0 & 0.0 & 40.0 & 0.0 & 0.0 \\
\hline Camptostoma obsoletum & $\mathrm{LC}$ & 3.3 & 12.5 & 57.0 & 7.7 & 25.9 \\
\hline Elaenia flavogaster & $\mathrm{LC}$ & 11.5 & 15.0 & 7.0 & 13.5 & 35.2 \\
\hline Myiopagis gaimardii & $\mathrm{LC}$ & 0.0 & 1.3 & 121.0 & 0.0 & 0.0 \\
\hline Capsiempis flaveola & $\mathrm{LC}$ & 3.3 & 12.5 & 0.0 & 13.5 & 46.3 \\
\hline Phaeomyias murina & $\mathrm{LC}$ & 3.3 & 0.0 & 0.0 & 0.0 & 0.0 \\
\hline Attila spadiceus & $\mathrm{LC}$ & 0.0 & 0.0 & 15.0 & 0.0 & 0.0 \\
\hline Legatus leucophaius & $\mathrm{LC}$ & 0.0 & 0.0 & 16.0 & 9.6 & 0.0 \\
\hline Myiarchus ferox & $\mathrm{LC}$ & 4.9 & 7.5 & 1.0 & 0.0 & 9.3 \\
\hline Myiarchus tyrannulus & $\mathrm{LC}$ & 1.6 & 0.0 & 1.0 & 0.0 & 0.0 \\
\hline Pitangus sulphuratus & $\mathrm{LC}$ & 42.6 & 30.0 & 41.0 & 1.9 & 26.9 \\
\hline Machetornis rixosa & $\mathrm{LC}$ & 0.0 & 2.5 & 0.0 & 0.0 & 0.0 \\
\hline Myiodynastes maculatus & $\mathrm{LC}$ & 0.0 & 0.0 & 7.0 & 0.0 & 0.0 \\
\hline Megarynchus pitangua & $\mathrm{LC}$ & 0.0 & 1.3 & 8.0 & 11.5 & 20.4 \\
\hline Myiozetetes similis & $\mathrm{LC}$ & 0.0 & 13.8 & 19.0 & 7.7 & 13.0 \\
\hline Tyrannus melancholicus & $\mathrm{LC}$ & 29.5 & 11.3 & 12.0 & 5.8 & 15.7 \\
\hline Fluvicola nengeta & $\mathrm{LC}$ & 1.6 & 2.5 & 1.0 & 0.0 & 0.0 \\
\hline Arundinicola leucocephala & $\mathrm{LC}$ & 1.6 & 0.0 & 0.0 & 0.0 & 0.0 \\
\hline Lathrotriccus euleri & $\mathrm{LC}$ & 0.0 & 1.3 & 30.0 & 0.0 & 0.0 \\
\hline
\end{tabular}


Appendix 1. Continue.

\begin{tabular}{|c|c|c|c|c|c|c|}
\hline \multirow[b]{2}{*}{ Family/Species } & \multirow[b]{2}{*}{ IUCN } & \multirow{2}{*}{$\begin{array}{c}\text { Pioneer } \\
\text { FBR }\end{array}$} & \multicolumn{2}{|c|}{ Ombrophilous } & \multicolumn{2}{|c|}{ Seasonal } \\
\hline & & & CTF & MTF & LGF & GPF \\
\hline \multicolumn{7}{|l|}{ Vireonidae (3) } \\
\hline Cyclarhis gujanensis & $\mathrm{LC}$ & 4.9 & 5.0 & 0.0 & 42.3 & 45.4 \\
\hline Vireo olivaceus & $\mathrm{LC}$ & 4.9 & 16.3 & 77.0 & 25.0 & 25.9 \\
\hline Hylophilus amaurocephalus & $\mathrm{LC}$ & 13.1 & 0.0 & 0.0 & 0.0 & 0.0 \\
\hline \multicolumn{7}{|l|}{ Hirundinidae (3) } \\
\hline Stelgidopteryx ruficollis & $\mathrm{LC}$ & 9.8 & 15.0 & 38.0 & 5.8 & 8.3 \\
\hline Progne tapera & $\mathrm{LC}$ & 0.0 & 0.0 & 3.0 & 0.0 & 0.0 \\
\hline Tachycineta albiventer & $\mathrm{LC}$ & 1.6 & 1.3 & 0.0 & 0.0 & 0.0 \\
\hline \multicolumn{7}{|l|}{ Troglodytidae (2) } \\
\hline Troglodytes musculus & $\mathrm{LC}$ & 1.6 & 11.3 & 32.0 & 15.4 & 25.9 \\
\hline Pheugopedius genibarbis & $\mathrm{LC}$ & 27.9 & 13.8 & 230.0 & 13.5 & 43.5 \\
\hline \multicolumn{7}{|l|}{ Polioptilidae (2) } \\
\hline Ramphocaenus melanurus & $\mathrm{LC}$ & 0.0 & 10.0 & 98.0 & 7.7 & 19.4 \\
\hline Polioptila plumbea & $\mathrm{LC}$ & 29.5 & 25.0 & 13.0 & 3.8 & 25.0 \\
\hline \multicolumn{7}{|l|}{ Turdidae (1) } \\
\hline Turdus leucomelas & $\mathrm{LC}$ & 0.0 & 50.0 & 2.0 & 65.4 & 25.9 \\
\hline \multicolumn{7}{|l|}{ Mimidae (2) } \\
\hline Mimus gilvus & $\mathrm{LC}$ & 36.1 & 0.0 & 0.0 & 0.0 & 0.0 \\
\hline Mimus saturninus & $\mathrm{LC}$ & 0.0 & 1.3 & 0.0 & 0.0 & 0.0 \\
\hline \multicolumn{7}{|l|}{ Coerebidae (1) } \\
\hline Coereba flaveola & $\mathrm{LC}$ & 0.0 & 2.5 & 76.0 & 1.9 & 0.9 \\
\hline \multicolumn{7}{|l|}{ Thraupidae (15) } \\
\hline Saltator maximus & $\mathrm{LC}$ & 0.0 & 1.3 & 0.0 & 0.0 & 0.0 \\
\hline Nemosia pileata & $\mathrm{LC}$ & 0.0 & 2.5 & 26.0 & 1.9 & 17.6 \\
\hline Thlypopsis sordida & $\mathrm{LC}$ & 0.0 & 0.0 & 0.0 & 0.0 & 5.6 \\
\hline Tachyphonus rufus & $\mathrm{LC}$ & 23.0 & 16.3 & 1.0 & 3.8 & 21.3 \\
\hline Ramphocelus bresilius ${ }^{*}$ & $\mathrm{LC}$ & 0.0 & 2.5 & 0.0 & 0.0 & 0.0 \\
\hline Lanio cristatus & $\mathrm{LC}$ & 0.0 & 2.5 & 7.0 & 0.0 & 0.0 \\
\hline Tangara fastuosa ${ }^{* *}$ & VU & 0.0 & 2.5 & 0.0 & 17.3 & 11.1 \\
\hline Tangara cyanocephala corallina ${ }^{* *}$ & $\mathrm{VU}^{1}$ & 0.0 & 0.0 & 0.0 & 28.8 & 1.9 \\
\hline Tangara sayaca & $\mathrm{LC}$ & 0.0 & 6.3 & 0.0 & 3.8 & 5.6 \\
\hline Tangara palmarum & $\mathrm{LC}$ & 0.0 & 7.5 & 63.0 & 151.9 & 120.4 \\
\hline Tangara cayana & $\mathrm{LC}$ & 6.6 & 26.3 & 6.0 & 11.5 & 57.4 \\
\hline Tersina viridis & $\mathrm{LC}$ & 0.0 & 3.8 & 0.0 & 0.0 & 0.0 \\
\hline Dacnis cayana & $\mathrm{LC}$ & 45.9 & 46.3 & 24.0 & 30.8 & 31.5 \\
\hline Cyanerpes cyaneus & $\mathrm{LC}$ & 0.0 & 8.8 & 0.0 & 0.0 & 10.2 \\
\hline Hemithraupis guira & $\mathrm{LC}$ & 0.0 & 31.3 & 5.0 & 40.4 & 24.1 \\
\hline \multicolumn{7}{|l|}{ Emberizidae (5) } \\
\hline Emberizoides herbicola & $\mathrm{LC}$ & 1.6 & 0.0 & 0.0 & 0.0 & 0.9 \\
\hline Volatinia jacarina & $\mathrm{LC}$ & 4.9 & 1.3 & 12.0 & 17.3 & 16.7 \\
\hline Sporophila nigricollis & $\mathrm{LC}$ & 0.0 & 0.0 & 3.0 & 0.0 & 4.6 \\
\hline Sporophila angolensis & $\mathrm{LC}$ & 0.0 & 1.3 & 0.0 & 0.0 & 0.0 \\
\hline Arremon taciturnus & $\mathrm{LC}$ & 0.0 & 17.5 & 50.0 & 19.2 & 24.1 \\
\hline \multicolumn{7}{|l|}{ Cardinalidae (1) } \\
\hline Caryothraustes canadenses frontalis ${ }^{*}$ & $\mathrm{VU}^{1}$ & 0.0 & 0.0 & 35.0 & 0.0 & 0.0 \\
\hline \multicolumn{7}{|l|}{ Parulidae (3) } \\
\hline Geothlypis aequinoctialis & $\mathrm{LC}$ & 1.6 & 0.0 & 0.0 & 0.0 & 0.0 \\
\hline
\end{tabular}


Appendix 1. Continue.

\begin{tabular}{lcccccc}
\hline & & Pioneer & \multicolumn{2}{c}{ Ombrophilous } & \multicolumn{2}{c}{ Seasonal } \\
Family/Species & IUCN & FBR & CTF & MTF & LGF & GPF \\
\hline Basileuterus culicivorus & LC & 0.0 & 35.0 & 3.0 & 0.0 & 0.0 \\
$\quad$ Basileuterus flaveolus & LC & 8.2 & 8.8 & 0.0 & 0.0 & 0.0 \\
Icteridae (2) & & & & & \\
$\quad \begin{array}{l}\text { Procacicus solitarius } \\
\text { Icterus cayanensis }\end{array}$ & LC & 0.0 & 0.0 & 0.0 & 0.0 & 0.9 \\
Fringillidae (2) & LC & 0.0 & 0.0 & 1.0 & 3.8 & 1.9 \\
$\quad$ Euphonia chlorotica & & & & & \\
$\quad$ Euphonia violacea & LC & 4.9 & 6.3 & 12.0 & 1.9 & 4.6 \\
\hline
\end{tabular}

Received 11 April 2012. Accepted 20 June 2013. ISSN 0073-4721

Article available at: www.scielo.br/isz 